\title{
МОЖЛИВОСТІ ВИКОРИСТАННЯ ПОРТОВИХ КОНТЕЙНЕРІВ У СУЧАСНОМУ МІСЬКОМУ СЕРЕДОВИЩІ
}

\section{POSSIBILITIES OF USING PORT CONTAINERS IN A MODERN URBAN ENVIRONMENT}

\author{
Ільчук Н. І.., к.т.н., доц., Олексин Х. А., магістр, (Луцький \\ національний технічний університет) \\ Ilchuk N.I., PhD, Associate professor, Oleksun X. A., master, (Lutsk \\ National Technical University)
}

Анотація. Проведено аналіз можливостей вторинного використання портових контейнерів. Проаналізовано існуючі комплекси у різних краӥнах. Визначено перспективи розвитку будівель різного функціонального призначення $з$ використаних портових контейнерів.

Summary. The possibility of reusing port containers has been analyzed. Analysis of existing complexes in different countries of the world. Prospects for the development of buildings of different functional purpose from port containers are determined. The functional purpose of the various types of buildings and structures that can be obtained when using containers of different sizes gives the prospect of their widespread use in urban development. Humanity is looking for ways to reduce its environmental footprint and become more environmentally conscious. The best and easiest way to do this is to build your home from recycled materials.

Buildings with port containers and pre-dominated plumbing blocks are a good option for establishing an essential comfortable living, office, commercial or administrative center. Analyzing the experience of using container containers in different countries of the world, and exploring the possibility of designing different functional buildings and structures, gives an opportunity to determine the perspective of their use in urban environments. The design of the container is a frame with a large enough carrying capacity. In fact, it is a constructor that is easy to assemble and disassemble, as well as easy to transport, decorate with any materials depending on the region and design idea.

A container is a sturdy and compact transport unit designed to carry heavy loads during shipping or land transportation of different materials, different in volume and storage conditions, which is what determines the design of the container.

When designing and constructing different functional buildings from port containers, all the advantages and disadvantages, as well as some features of their use, should be taken into account. The construction of houses from block containers is carried out in a short time - from a week to a month. Such advantages make buildings with port containers and converted cargo units an excellent option for creating a modern comfortable home, office, shopping or administrative center.

Ключові слова: портові контейнери, вантажні блоки, модульні будівлі Keywords:port containers, cargo blocks, modular buildings 
Постановка проблеми. За останні кілька десятиліть значно збільшився вплив на навколишнє середовище, а саме - його забруднення як результат діяльності людини. Тому питання вторинного використання портових контейнерів, які вже виведено з експлуатації, $є$ досить доцільним та потрібним для сьогодення.[1,2].

Аналіз відомих досліджень i публікацій. Аналіз досвіду використання портових контейнерів у різних країнах світу та дослідження можливості проектування різних за функціональним призначенням будівель та споруд дає можливість визначити перспективу їх використання у міському середовищі. Людство шукає способи зменшити свій вплив на природне середовище і стати більш екологічно свідомим. Кращий i найпростіший спосіб зробити це - побудувати свій будинок 3 перероблених матеріалів. Численні опитування мешканців модульних будівель по всій Європі показали, що екологічність будинку займає пріоритетну позицію для людей, які обирають контейнерне будівництво [3-4].

Кількість людей, які усвідомлюють свій вплив на навколишнє середовище, істотно збільшується.

Мета статті: проаналізувати можливості проектування будівель 3 портових контейнерів в Україні, які можна отримати при використанні різних за розміром портових контейнерів та вантажних блоків.

Відповідно до поставленої мети вирішуються наступні завдання:

-проаналізувати можливості використання портових контейнерів при проектуванні різних будівель та споруд в міському середовищі;

-проаналізувати доцільність використання портових контейнерів при проектуванні різних будівель та споруд в міському середовищі;

- запропонувати проект модульних будівель, різного функціонального призначення для благоустрою міської території.

Аналіз можливості використання портових контейнерів. На міжнародному будівельному ринку досить давно використовують цікаву ідею - будівництво $з$ портових контейнерів.

Конструкція контейнера - рама 3 досить великою несучою здатністю - один контейнер може витримати ще 10 контейнерів, які можна поставити зверху. В країнах Європи досить часто використовують такий спосіб зведення будівель різного функціонального призначення. Фактично це конструктор, який легко можна зібрати і розібрати, а також, його легко транспортувати, оздоблення виконують будь-якими матеріалами в залежності від регіону та дизайнерської ідеї.

Функціональне призначення будівель досить різне, крім житлового будівництва - це готелі, кафе, точки роздрібної торгівлі та торгові центри, адміністративні будівлі, офісні центри та багато інших будівель. Контейнер - це міцний і компактний транспортний блок, розрахований на 
велике навантаження під час морських або сухопутніх транспортувань різних матеріалів, різних за об'ємом та умовами зберігання, саме це й визначає конструкцію контейнера.

Вантажний модуль для морських перевезень складається зі зварного каркаса, зібраного з профільованих сталевих балок. Стіни і стелю боксу обшивають профільованим листовим металом товщиною 1,5 мм, захищеним від корозії подвійним шаром фарби. Підлогу вистилають дошками або багатошаровою фанерою, обробленою композитним складом. Модуль обладнаний торцевими воротами для швидкого навантаження або розвантаження матеріалів. Існують моделі з бічним або вертикальним завантаженням, а також для негабаритних вантажів - моделі з висувним верхом.

Контейнер 20 футів, конструкція якого передбачає переміщення за допомогою навантажувача, оснащений бічними кишенями. Прорізи в нижній балці забезпечують надійну фіксацію боксу під час руху транспортного засобу.

Конструкція контейнера 40 футів виключає можливість використання навантажувача через високу ймовірність втрати рівноваги. Переміщення модуля здійснюють за допомогою кутових фітингів і спеціальних підйомних пристроїв. Сталевий бокс оснащений тунелем для автопричепу. На внутрішній поверхні вантажу встановлені кільця або кріплення для фіксації нестандартних вантажів.

Блок-контейнер відрізняється від стандартного морського боксу внутрішньою будовою стін і стелі. Облаштування модуля передбачає попереднє утеплення, гідроізоляцію та інтер'єрну обробку, його використовують в якості мобільного складу, лабораторії, офісу, посту охорони, медпункту або житлового приміщення. В стіни боксу врізають вікна і двері для створення комфортних умов житлової або робочої зони. Універсальна конструкція дозволяє оперативно переміщувати об'єкти будь-яким доступним транспортом.

Сталевий каркас стає основою нового будинку. Конструкцію піддають переоснащенню та утеплюють. Всередині прокладають необхідні комунікації, створюють приємний мікроклімат, комплектують меблями та побутовими приладами. Готовий будинок переміщують на вибрану ділянку.

3 блок-контейнерів досить легко можна зібрати різні будівлі 3 великими вікнами, мансардами, балконами та верандами. Також $є$ можливість переміщення мобільних конструкцій без демонтажу інтер'єру приміщень, а також виконати модернізацію комплексу шляхом збільшення кількості приміщень.

Стіна контейнера товщиною 12 см має теплопровідність, яка відповідає стіні 3 цегляної кладки товщиною 1,5 м або триметровій бетонній конструкції. Багатошаровий принцип утеплення забезпечує 
комфортні умови в північних регіонах з холодним і вологим кліматом. Енергоефективні комплекси дозволяють економити кошти на опалення i вентиляцію приміщень. Об'єднуючи окремі блоки, можна створювати масштабні конструкції будь-якої площі (рис.1, 2) [3].

Для прикладу, Agaligo Studio використали контейнери для престижного річкового курорту X2 RiverKwaiResort. Комплекс складається з 6-ти контейнерів X-Float, які ніби пливуть по воді. При такому виконанні проектних рішень, 3 номерів готелю відкривається неймовірний вигляд на річку і створюється ефект рухомого об'єкту (рис.2).

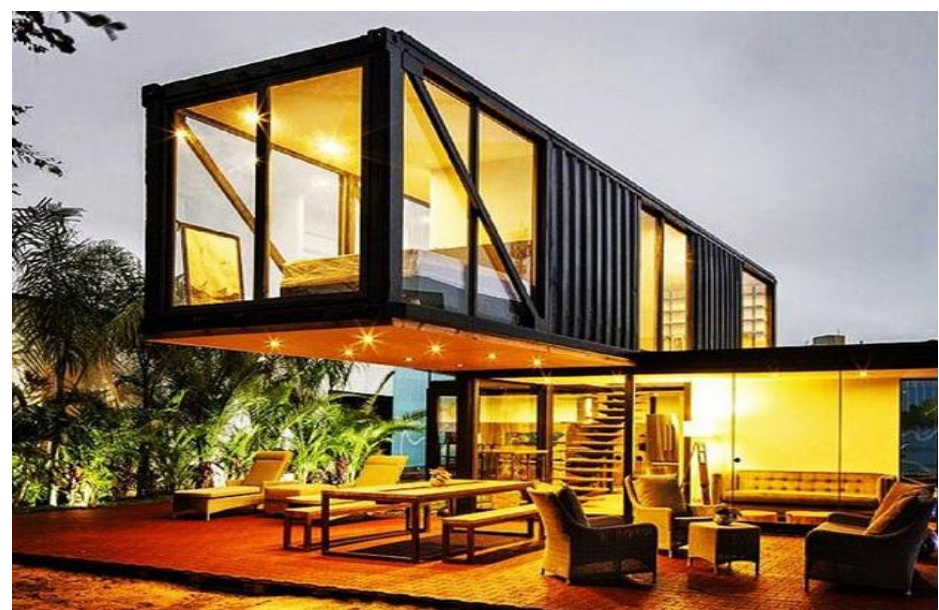

Рис.1. Будинок, виконаний 32 контейнерів.
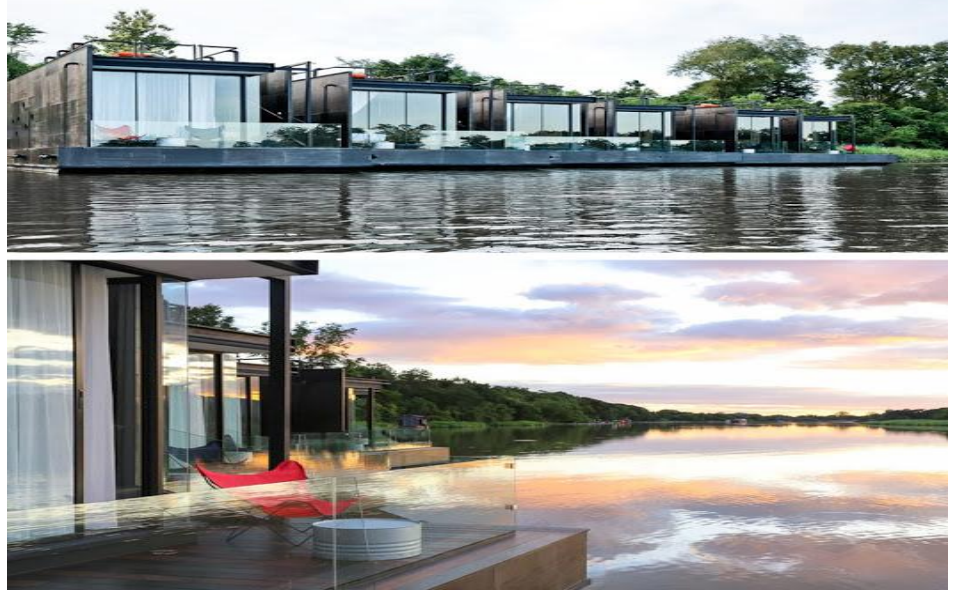

Рис.2. Річковий курорт із контейнерів 
Аналіз можливості використання портових контейнерів в Україні.Українські архітектори також не відстають від тенденцій у світі контейнерної архітектури. Для прикладу, у Харкові архітектор Олег Дроздов (Drozdov\&Partners) розробив проект житлового будинку Antipatio. Його площа складає 130 кв.м. і розташований він на схилі пагорба, що є головною перевагою, адже мешканцям будинку відкривається приголомшлива панорама. Очевидно, що у вітальній зоні передбачені панорамні вікна.

Будівля зібрана з трьох контейнерів площею 60 кв.м кожен. Два 3 них розташовані перпендикулярно один поверх іншого і формують основну будівлю, в той час, як третій контейнер стоїть одноосібно і $є$ гостьовим блоком. Перший поверх представлений вітальною зоною, а на другому спроектована спальна частина (рис.3).

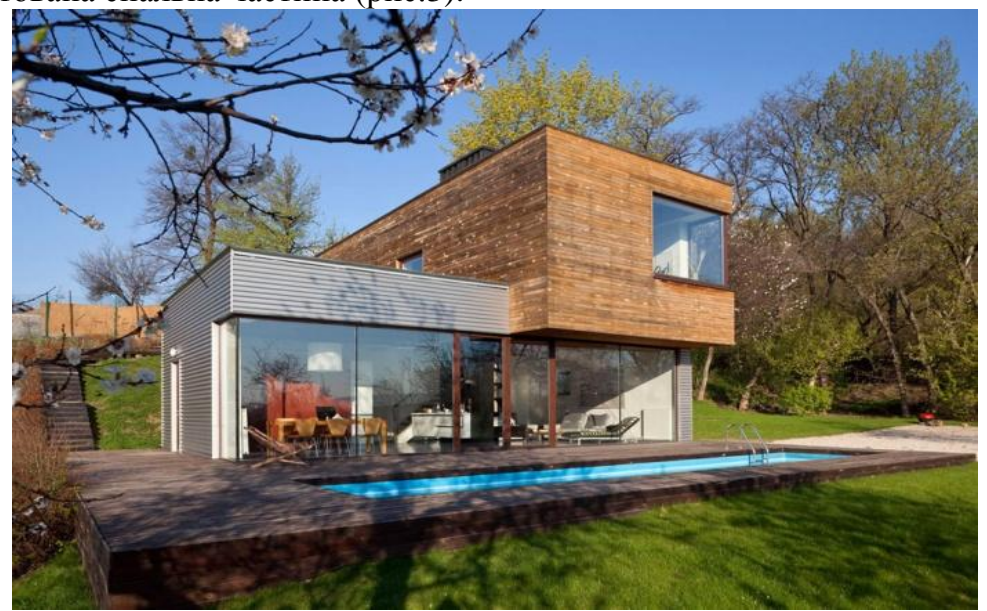

Рис.3. Будинок з контейнерів у м. Харкові

Аналіз можливості використання портових контейнерів при проектуванні різних будівель і споруд у міському середовищі. При проектуванні та будівництві різних за функціональним призначенням будівель 3 портових контейнерів потрібно враховувати усі переваги та недоліки, а також деякі особливості їх використання. Будівництво будинків з блок-контейнерів здійснюється в короткі терміни - від тижня до місяця, тому є можливість вести будівництво протягом року; можна зробити утеплення всередині та використовувати будівлі з контейнерів в будь-яку пору року, цим самим пристосувати житло до будь-яких кліматичних умов. Порівняно недорога вартість робіт при монтажі, можливість побудувати економічний фундамент. Маса блоків невелика (24 тонни) i не вимагає зміцнення фундаменту; можливо зробити полегшений фундамент для будинку на блоках або палях. Висока 
мобільність - це зручність перевезення контейнерів, швидке будівництво i демонтаж при необхідності. Виконання внутрішнього оздоблення сучасними якісними матеріалами всередині модулів, а також привабливий зовнішній вигляд. Стіни таких конструкцій вертикальні, їх не треба рівняти i додатково використовувати матеріали, точна відповідність внутрішніх розмірів. Вогнезахисне покриття всередині і зовні контейнера. Міцність стін і захист від проникнення грабіжників. Швидке і легке підключення водопостачання і електрики, а також можливість монтажу теплої підлоги. Можливість вільного компонування і створення будь яких форм конструкцій. Довговічність блок-контейнерів, що дозволяє продовжити термін експлуатації до 50 років.

Хоча найбільшою перевагою будівництва з використанням портових i транспортних контейнерів вважається екологічна складова. Щоразу, коли стандартний 40-футовий контейнер підлягає утилізації, переробці піддається 3500 кг сталі. За оцінками експертів, щороку близько 500000 контейнерів для перевезення перестають використовуватися за прямим призначенням. Крім того, існує кілька мільйонів транспортних контейнерів, які вже виведені $з$ експлуатації. Це величезна кількість корисного будівельного матеріалу.

Проект модульних будівель різного функціонального призначення для благоустрою міської території. При розробці магістерської дипломної роботи було розроблено пропозицію щодо офісного центру із блок-контейнерів. Частина контейнерів лежить на стрічковому фундаменті. Частина - покладена зверху, утворюючи другий поверх. Один 3 контейнерів лежить під кутом 30 градусів. У цьому контейнері передбачено встановлення сходів. У деяких контейнерах передбачено зовнішні прорізи для встановлення віконних блоків. Всередині деяких контейнерів теж $€$ прорізи, що дає можливість сформувати внутрішній простір встановленням дверей i системи коридорів. Для забезпечення надійності вся конструкція складена навколо «скелета» зі сталевих паль і балок, які також між собою зварені (рис.4).

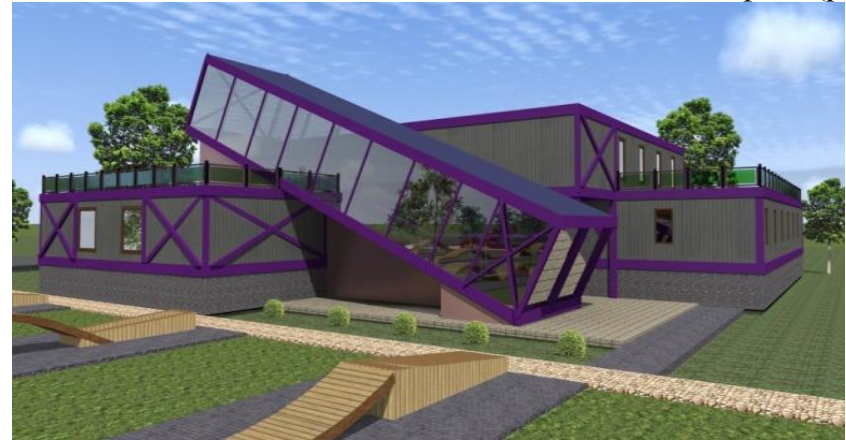

Рис.4. Офісний центр 
Проектом також передбачено будівництво кафе 3 контейнерів, 3 благоустроєм прилеглої території, що дає можливість реалізувати даний проект у будь-якому міському середовищі. Досить цікавим акцентом є те, що один із контейнерів розміщений вертикально (рис.5).

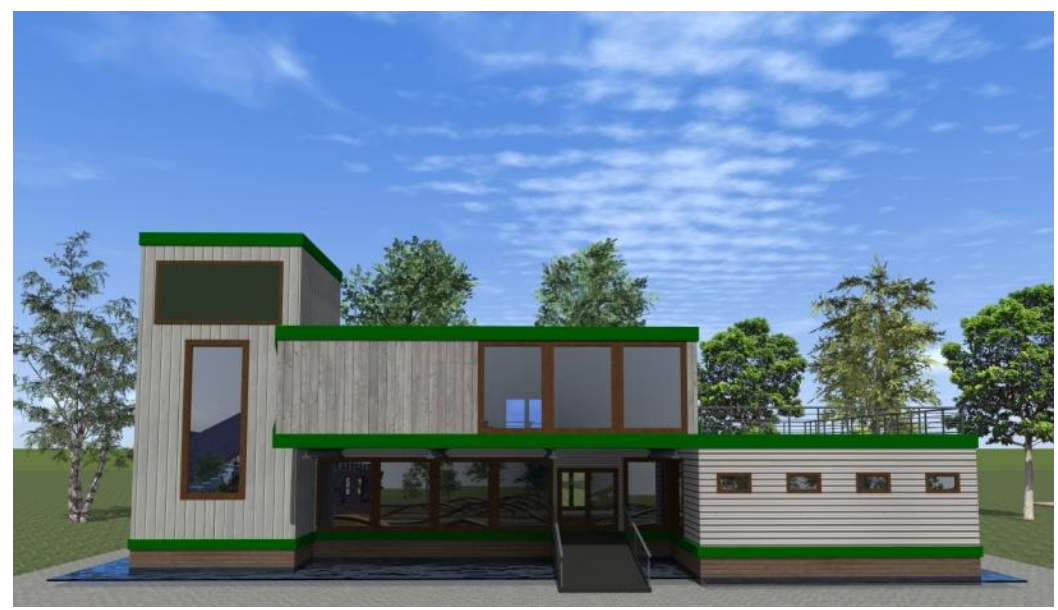

Рис.5. Кафе з морських контейнерів

Контейнерна архітектура зустрічається в усьому світі і дані будівлі успішно можна використовувати в будівництві на території України. Перераховані вище переваги роблять будівлі з портових контейнерів і переобладнаних вантажних блоків відмінним варіантом для створення сучасного комфортного житла, офісу, торгового або адміністративного центру.

\section{Висновки.}

У результаті проведеного аналізу встановлено доцільність використання портових контейнерів та вантажних блоків при проектуванні різних будівель та споруд широко використовується в різних країнах світу. Доцільність використання зумовлюється екологічністю, енергоефективністю а також, відносно невисокою вартістю будівництва.

Як проектна пропозиція запропоновано будівництво офісного центру та кафе для благоустрою міської території.

\footnotetext{
References

1.Oficijny`jsajt «FUT KONTEJNER» - Rezhy`mdostupu: https://footcontainer.ru/about/

2.Oficijny`jsajt «eksKONTEJNER»-Rezhy`mdostupu: https://www.excontainer.com.ua/cafe_evrokoleso/
} 
3.«Superdom» - Rezhy`mdostupu: https://superdom.ua/view/kafe-iz-morskihkontejnerov.html

4. Containex - firma-destry`byutor kontejneriv v Ukrayini http://www.containex.ua/uk/produkty/ofisnyj-blok-kontejner

5. DBN B.2.2 - 12:2018 «Planuvannyaizabudovatery`torij»

6.DBN B.1.1-22:2017 «Sklad ta zmistplanuzonuvannyatery`torij»

7.Planuvannyamist :pidruchny`k / V.V. Didy`k, A.P. Pavliv ; Nacz. un-t "L`vivs`kapolitexnika", 2006.- 412 s.

8.Planuvannyamist i transport: Navchal`ny`jposibny`k. O.S. Bezlyubchenko, S.M. Gordiyenko, O.V. Zaval`ny`j. - Xarkiv: XNAMG, 2008. - 156 s.

9.Urbanisty`ka: Navch. posibny`k/ O.S. Bezlyubchenko, O.V. Zaval`ny`j. -Xarkiv: XDAMG, 2003.- 254 s.

\section{Список використаної літератури}

container.ru/about/

1.Офіційний сайт «ФУТ КОНТЕЙНЕР» - Режим доступу: https://foot-

2.Офіційний сайт «ексКОНТЕЙНЕР» - Режим доступу: https://www.excontainer.com.ua/cafe_evrokoleso/

3. «Superdom» - Режим доступу: https://superdom.ua/view/kafe-iz-morskihkontejnerov.html

4.Containex - фірма-дестрибютор контейнерів в Україні http://www.containex.ua/uk/produkty/ofisnyj-blok-kontejner

5. ДБН Б.2.2 - 12:2018 « Планування і забудова територій»

6. ДБН Б.1.1-22:2017 «Склад та зміст плану зонування територій»

7.Планування міст : підручник / В.В. Дідик, А.П. Павлів ; Нац. ун-т "Львівська політехніка", 2006.- 412 с.

8.Планування міст і транспорт: Навчальний посібник. О.С. Безлюбченко, С.М. Гордієнко, О.В. Завальний. - Харків: ХНАМГ, 2008. - 156 с.

9. Урбаністика: Навч. посібник/ О.С. Безлюбченко, О.В. Завальний. -Харків: ХДАМГ, 2003.- 254 c. 